\title{
Time Course of the Size of the Dark Area in Macular Holes by Scanning Laser Ophthalmoscopy
}

\author{
Yoshiko Akasaka, Shimpei Nishikawa and Makoto \\ TAMAI \\ Department of Ophthalmology, Tohoku University School of \\ Medicine, Sendai 980-8574
}

\begin{abstract}
Akasaka, Y., Nishikawa, S. and Tamai, M. Time Course of the Size of the Dark Area in Macular Holes by Scanning Laser Ophthalmoscopy. Tohoku J. Exp. Med., 2000, 190 (2) 93-101 — To investigate the time course of idiopathic macular hole development by scanning laser ophthalmoscopy (SLO), we examined 28 eyes of 25 patients with macular holes. Cases included four eyes with stage 1-B disease (foveal detachment), 3 with stage 2 (break at the fovea), 13 with stage 3 (full-thickness macular hole), and 8 with stage 4 (hole with pseudo-operculum, posterior vitreous detachment), according to Gass's classification. The diameter of the dark area around the macular holes was recorded by SLO using a helium-neon laser. We compared the percent difference of dark area recorded between initial findings and these after three months. The size of the dark area increased after three months in eyes with stages 1,2 , and 3 disease. The size of the dark area in stage 4 disease decreased after 3 months. In the stage before posterior vitreous detachment (PVD), the dark areas increased. Once PVD occurred, these areas decreased. These findings suggested that the time course of the dark area may be related to the development of PVD. macular hole; posterior vitreous detachment; optical coherence tomography (C) 2000 Tohoku University Medical Press
\end{abstract}

Idiopathic full-thickness macular holes are a relatively common cause of unilateral central visual loss in the elderly persons. Recent advances in the surgical treatment of macular holes have increased the ability to restore vision or prevent central visual loss with macular holes. Macular holes have been diagnosed using several techniques (Guez et al. 1998). Scanning laser ophthalmoscopy (SLO) gives a more contrasted image of the macula than fundus photographs in macular diseases. Successful imaging with SLO has been reported in studies of macular holes (Kishi et al. 1995). In the present study, we investigated the time course of idiopathic macular hole by SLO. The origin of the dark area

Received September 21, 1999; revision accepted for publication January 20, 2000. Address for reprints: Yoshiko Akasaka, M.D., Department of Ophthalmology, Tohoku University School of Medicine, Sendai 980-8574, Japan.

e-mail: AKASAKA@oph.med.tohoku.ac.jp 
is unknown. Optical coherence tomography $(\mathrm{OCT})$ is a new diagnostic imaging technique that produces a high resolution view of the anterior and posterior regions of the eyes (Hee et al. 1993; Swanson et al. 1993). Recently, we compared cystic spaces with the dark areas around macular holes by OCT. The diameters of the dark areas were in proportion to the size of the cystic spaces (Akasaka et al. 1999). In this report we examined the time course of idiopathic macular holes in each stage.

\section{Patients and Methods}

A total of 28 eyes of 25 patients ( 14 men, 11 women; age $64.6 \pm 5.0$ years, Mean \pm s.D.) with the clinical diagnosis of macular hole were examined by SLO at Tohoku University Hospital (Table 1). Patients must have had no coexisting retinal disease that could affect the functional status of the macula and no evidence of aphakic or pseudophakic cystoid macular edema.

Cases included 4 eyes with stage 1-B disease (foveal detachment), 3 eyes with stage 2 (break at the fovea), 13 eyes with stage 3 (full-thickness macular hole), and 8 eyes with stage 4 (hole with pseudo-operculum, posterior vitreous detachment), according to Gass's classification (Gass 1995). Twenty healthy eyes were examined as controls.

Baseline data included visual acuity testing, fellow eye diagnosis, stage of macular hole, status of vitreous, presence of pseudo-operculum, the size of dark area around holes, and the presence of an associated macular disease. At fundus examination the patient's pupils were dilated, and was performed slit-lamp microscopy with use of a double aspheric noncontact lens and Goldmann threemirror contact lens. We used SLO (Rodenstock Instruments, Munich, Germany) developed by Mainster et al. (1982). The image of the fundus was $40 \times 40$ degrees and $20 \times 20$ degrees. The fundus was illuminated by an argon green laser (514 $\mathrm{nm})$ and a helium-neon laser $(633 \mathrm{~nm})$.

\section{Quantitative analysis}

The transverase diameter of the dark area in SLO was measured manually. Percent difference of the size of the dark area between initial findings and those recorded after three months (mean \pm s.E.) was calculated, and OCT was performed.

We used Student's $t$-test for statistical analysis.

\section{ResUlts}

\section{Stage 1-B impending macular hole}

Four eyes with stage 1-B macular holes had a foveolar detachment. When seen by SLO with the argon laser, the superficial retinal layer appeared to be lifted from the deeper retinal layer. Helium-neon light showed a round dark area, where a round contour of an intraretinal cyst was seen (Fig. 1, top left). OCT described a perifoveal detachment of the posterior vitreous with significant 
TABLE 1. Summary of patient characteristics

\begin{tabular}{|c|c|c|c|c|c|}
\hline $\begin{array}{l}\text { Patient } \\
\text { No. }\end{array}$ & $\begin{array}{l}\text { Sex/ } \\
\text { Age, y }\end{array}$ & Eye & $\begin{array}{l}\text { Visual } \\
\text { acuity }\end{array}$ & Macular status & $\begin{array}{c}\text { Vitreous } \\
\text { status }\end{array}$ \\
\hline 1 & $\begin{array}{l}\mathrm{F} \\
59\end{array}$ & $\begin{array}{l}\mathrm{R} \\
\mathrm{L}\end{array}$ & $\begin{array}{l}20 / 60 \\
20 / 20\end{array}$ & $\begin{array}{l}\text { Stage 1B } \\
\text { Normal }\end{array}$ & $\begin{array}{l}\text { Attached } \\
\text { Attached }\end{array}$ \\
\hline 2 & $\begin{array}{l}\mathrm{M} \\
69\end{array}$ & $\begin{array}{l}\mathrm{R} \\
\mathrm{L}\end{array}$ & $\begin{array}{l}20 / 50 \\
20 / 30\end{array}$ & $\begin{array}{l}\text { Stage 1B } \\
\text { Normal }\end{array}$ & $\begin{array}{l}\text { Attached } \\
\text { Attached }\end{array}$ \\
\hline 3 & $\begin{array}{l}\mathrm{F} \\
60\end{array}$ & $\begin{array}{l}\mathrm{R} \\
\mathrm{L}\end{array}$ & $\begin{array}{l}20 / 20 \\
20 / 20\end{array}$ & $\begin{array}{l}\text { Stage 1B } \\
\text { Normal }\end{array}$ & $\begin{array}{l}\text { Attached } \\
\text { Attached }\end{array}$ \\
\hline 4 & $\begin{array}{l}\mathrm{F} \\
56\end{array}$ & $\begin{array}{l}\mathrm{R} \\
\mathrm{L}\end{array}$ & $\begin{array}{l}20 / 40 \\
20 / 100\end{array}$ & $\begin{array}{l}\text { Stage 1B } \\
\text { Stage } 3\end{array}$ & $\begin{array}{l}\text { Attached } \\
\text { Attached }\end{array}$ \\
\hline 5 & $\begin{array}{l}\mathrm{M} \\
69\end{array}$ & $\begin{array}{l}\mathrm{R} \\
\mathrm{L}\end{array}$ & $\begin{array}{l}20 / 20 \\
20 / 40\end{array}$ & $\begin{array}{l}\text { Normal } \\
\text { Stage } 2\end{array}$ & $\begin{array}{l}\text { Attached } \\
\text { Attached }\end{array}$ \\
\hline 6 & $\begin{array}{l}\mathrm{M} \\
66\end{array}$ & $\begin{array}{l}\mathrm{R} \\
\mathrm{L}\end{array}$ & $\begin{array}{l}20 / 20 \\
20 / 100\end{array}$ & $\begin{array}{l}\text { Normal } \\
\text { Stage } 2\end{array}$ & $\begin{array}{l}\text { Attached } \\
\text { Attached }\end{array}$ \\
\hline 7 & $\begin{array}{l}\mathrm{M} \\
69\end{array}$ & $\begin{array}{l}\mathrm{R} \\
\mathrm{L}\end{array}$ & $\begin{array}{l}20 / 100 \\
20 / 100\end{array}$ & $\begin{array}{l}\text { Stage 1B } \\
\text { Stage } 2\end{array}$ & $\begin{array}{l}\text { Attached } \\
\text { Attached }\end{array}$ \\
\hline 8 & $\begin{array}{l}\mathrm{F} \\
64\end{array}$ & $\begin{array}{l}\mathrm{R} \\
\mathrm{L}\end{array}$ & $\begin{array}{l}20 / 100 \\
20 / 20\end{array}$ & $\begin{array}{c}\text { Stage } 3 \text { hole with operculum } \\
\text { Normal }\end{array}$ & $\begin{array}{l}\text { Attached } \\
\text { Attached }\end{array}$ \\
\hline 9 & $\begin{array}{l}\mathrm{F} \\
61\end{array}$ & $\begin{array}{l}\mathrm{R} \\
\mathrm{L}\end{array}$ & $\begin{array}{l}20 / 100 \\
20 / 200\end{array}$ & $\begin{array}{l}\text { Stage } 3 \text { hole } \\
\text { Normal* }\end{array}$ & $\begin{array}{l}\text { VFS } \\
\text { PVS }\end{array}$ \\
\hline 10 & $\begin{array}{l}\mathrm{M} \\
69\end{array}$ & $\begin{array}{l}\mathrm{R} \\
\mathrm{L}\end{array}$ & $\begin{array}{l}20 / 25 \\
20 / 200\end{array}$ & $\begin{array}{l}\text { Para foveal RP atrophy } \\
\text { Stage } 3 \text { hole }\end{array}$ & $\begin{array}{c}\text { PVS } \\
\text { Attached }\end{array}$ \\
\hline 11 & $\begin{array}{c}\mathrm{F} \\
55\end{array}$ & $\begin{array}{l}\mathrm{R} \\
\mathrm{L}\end{array}$ & $\begin{array}{l}20 / 50 \\
20 / 20\end{array}$ & $\begin{array}{l}\text { Stage } 3 \text { hole } \\
\text { Normal }\end{array}$ & $\begin{array}{l}\text { Attached } \\
\text { Attached }\end{array}$ \\
\hline 12 & $\begin{array}{l}\mathrm{F} \\
61\end{array}$ & $\begin{array}{l}\mathrm{R} \\
\mathrm{L}\end{array}$ & $\begin{array}{l}20 / 60 \\
20 / 20\end{array}$ & $\begin{array}{l}\text { Stage } 3 \text { hole } \\
\text { Normal }\end{array}$ & $\begin{array}{l}\text { Attached } \\
\text { Attached }\end{array}$ \\
\hline 13 & $\begin{array}{l}\mathrm{M} \\
56\end{array}$ & $\begin{array}{l}\mathrm{R} \\
\mathrm{L}\end{array}$ & $\begin{array}{l}20 / 20 \\
20 / 40\end{array}$ & $\begin{array}{c}\text { Stage 1A } \\
\text { Stage } 3 \text { hole }\end{array}$ & $\begin{array}{l}\text { Attached } \\
\text { Attached }\end{array}$ \\
\hline 14 & $\begin{array}{l}\text { M } \\
66\end{array}$ & $\begin{array}{l}\mathrm{R} \\
\mathrm{L}\end{array}$ & $\begin{array}{l}20 / 100 \\
20 / 20\end{array}$ & $\begin{array}{c}\text { Stage } 3 \text { hole with operculum } \\
\text { Stage } 1 \mathrm{~A}\end{array}$ & $\begin{array}{l}\text { Attached } \\
\text { Attached }\end{array}$ \\
\hline 15 & $\begin{array}{l}\text { M } \\
66\end{array}$ & $\begin{array}{l}\mathrm{R} \\
\mathrm{L}\end{array}$ & $\begin{array}{l}20 / 20 \\
20 / 60\end{array}$ & $\begin{array}{c}\text { Stage 1A } \\
\text { Stage } 3 \text { hole }\end{array}$ & $\begin{array}{l}\text { Attached } \\
\text { Attached }\end{array}$ \\
\hline 16 & $\begin{array}{l}\mathrm{M} \\
66\end{array}$ & $\begin{array}{l}\mathrm{R} \\
\mathrm{L}\end{array}$ & $\begin{array}{l}20 / 100 \\
20 / 60\end{array}$ & $\begin{array}{l}\text { Stage } 3 \text { hole } \\
\text { Stage } 3 \text { hole }\end{array}$ & $\begin{array}{c}\text { VFS } \\
\text { Attached }\end{array}$ \\
\hline 17 & $\begin{array}{c}\mathrm{F} \\
64\end{array}$ & $\begin{array}{l}\mathrm{R} \\
\mathrm{L}\end{array}$ & $\begin{array}{l}20 / 400 \\
20 / 100\end{array}$ & $\begin{array}{c}\text { Stage } 4 \text { hole } \\
\text { Stage } 3 \text { hole with operculum }\end{array}$ & $\begin{array}{c}\text { PVS } \\
\text { Attached }\end{array}$ \\
\hline 18 & $\begin{array}{l}\text { M } \\
66\end{array}$ & $\begin{array}{l}\mathrm{R} \\
\mathrm{L}\end{array}$ & $\begin{array}{l}20 / 30 \\
20 / 20\end{array}$ & $\begin{array}{l}\text { Stage } 3 \text { hole with operculum } \\
\text { Stage } 3 \text { hole with operculum }\end{array}$ & $\begin{array}{l}\text { Attached } \\
\text { Attached }\end{array}$ \\
\hline 19 & $\begin{array}{l}\mathrm{F} \\
63\end{array}$ & $\begin{array}{l}\mathrm{R} \\
\mathrm{L}\end{array}$ & $\begin{array}{l}20 / 20 \\
20 / 200\end{array}$ & $\begin{array}{c}\text { Stage } 3 \text { hole with operculum } \\
\text { Lamellar hole }\end{array}$ & $\begin{array}{l}\text { Attached } \\
\text { PVS }\end{array}$ \\
\hline 20 & $\begin{array}{l}\mathrm{M} \\
71\end{array}$ & $\begin{array}{l}\mathrm{R} \\
\mathrm{L}\end{array}$ & $\begin{array}{l}20 / 100 \\
20 / 20\end{array}$ & $\begin{array}{l}\text { Stage } 4 \\
\text { Normal }\end{array}$ & $\begin{array}{l}\text { PVS } \\
\text { PVS }\end{array}$ \\
\hline 21 & $\begin{array}{l}\mathrm{M} \\
61\end{array}$ & $\begin{array}{l}\mathrm{R} \\
\mathrm{L}\end{array}$ & $\begin{array}{l}20 / 100 \\
20 / 20\end{array}$ & $\begin{array}{l}\text { Stage } 4 \\
\text { Normal }\end{array}$ & $\begin{array}{l}\text { Attached } \\
\text { Attached }\end{array}$ \\
\hline 22 & $\begin{array}{l}\mathrm{M} \\
75\end{array}$ & $\begin{array}{l}\mathrm{R} \\
\mathrm{L}\end{array}$ & $\begin{array}{l}20 / 30 \\
20 / 400\end{array}$ & $\begin{array}{l}\text { Lamellar hole } \\
\text { Stage } 4\end{array}$ & $\begin{array}{l}\text { PVS } \\
\text { PVS }\end{array}$ \\
\hline 23 & $\begin{array}{l}\mathrm{F} \\
63\end{array}$ & $\begin{array}{l}\mathrm{R} \\
\mathrm{L}\end{array}$ & $\begin{array}{l}20 / 100 \\
20 / 200\end{array}$ & $\begin{array}{l}\text { Lamellar hole } \\
\quad \text { Stage } 4\end{array}$ & $\begin{array}{l}\text { PVS } \\
\text { PVS }\end{array}$ \\
\hline
\end{tabular}


Table 1. Continued

\begin{tabular}{cccccc}
\hline $\begin{array}{c}\text { Patient } \\
\text { No. }\end{array}$ & $\begin{array}{c}\text { Sex/ } \\
\text { Age, y }\end{array}$ & Eye & $\begin{array}{c}\text { Visual } \\
\text { acuity }\end{array}$ & Macular status & $\begin{array}{c}\text { Vitreous } \\
\text { status }\end{array}$ \\
\hline 24 & M & R & $20 / 20$ & Normal & PVS \\
& 67 & L & $20 / 100$ & Stage 4 & PVS \\
25 & F & R & $20 / 20$ & Stage 1A & Attached \\
& 69 & L & $20 / 400$ & Stage 4 & PVS \\
26 & M & R & $20 / 20$ & Normal & Attached \\
& 69 & L & $20 / 200$ & Stage 4 & PVS \\
\hline
\end{tabular}

*Patient of case 9 have a decreased visual acuity, the reason is ametropic amblyopia. VFS, vitreofoveal separation; PVS, posterior vitreous separation; $y$, year.

vitreofoveal traction, which appeared to disrupt the normal structure of the foveal pit (Fig. 1, bottom left). Three months later, the dark area enlarged by SLO (Fig. 1, top right). The cystic formation in the foveal center enlarged after three months by OCT (Fig. 1, bottom right).

\section{Stage 2 hole}

Three eyes with stage 2 holes had an eccentric or central round defect with rim of elevated retina. This break was seen as a high-intensity reflex on illumination with argon green laser light. Helium-neon light showed the elevated rim of foveolar break (Fig. 2, top left). OCT described a full-thickness hole with an attached operculum and surrounding edema (Fig. 2, bottom left). Three months later, the dark area enlarged (Fig. 2, top right). OCT described an enlarged hole with detached operculum (Fig. 2, bottom right).

\section{Stage 3 hole}

Thirteen eyes with stage 3 macular holes had an elevated rim and were macular hole rim surrounded by the dark area and radiating striae of Henle's fiber layer, as demonstrated with the helium-neon laser (Fig. 3, top left). The opercula were thin and located immediately anterior to the hole. OCT showed a classic stage 3 hole with a large operculum anterior to the retina and a wide halo of retinal edema (Fig. 3, bottom left). Three months later, the dark area enlarged (Fig. 3, top right). OCT showed same findings as initial (Fig. 3, bottom right).

\section{Stage 4 hole}

Eight eyes with stage 4 holes showed the same SLO findings as eyes with stage 3 disease (Fig. 4, top left). OCT demonstrated a full-thickness hole and a complete separation of the posterior hyaloid membrane from the retina (Fig. 4, bottom left). Three months later, the dark area slightly decreased by SLO using heliumneon laser (Fig. 4, top right). OCT showed same findings as initial (Fig. 4, bottom right). 

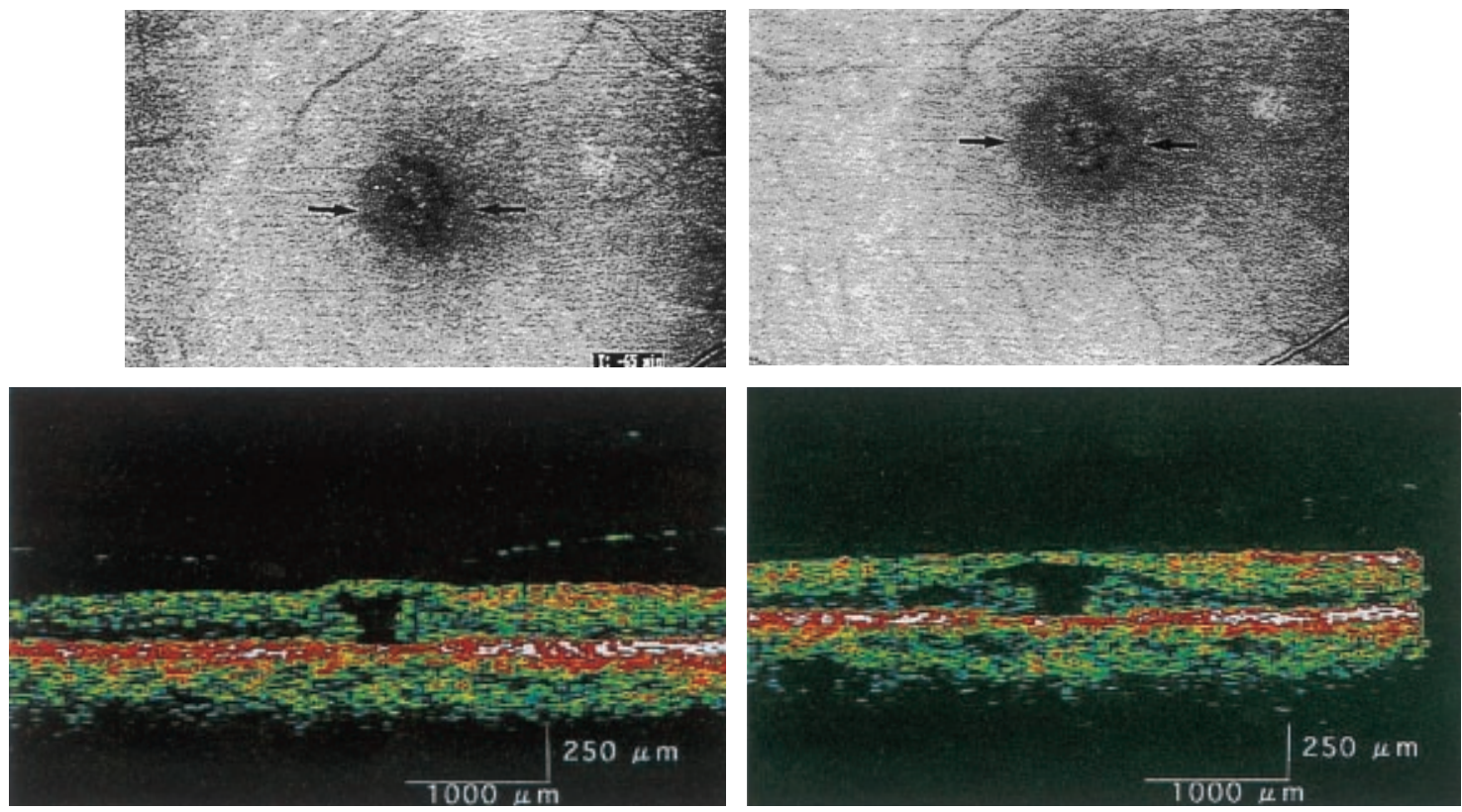

Fig. 1. Case 1. Stage 1-B impending macular hole. Top left, initial findings by scanning laser ophthalmoscopy. Helium-neon laser shows a round dark area (arrows). Bottom left, a horizontal optical coherence tomograph shows a minimally reflective space within the neurosensory retina. Top right, scanning laser ophthalmoscopy taken after three months (arrows). The dark area enlarged. Bottom right, optical coherence tomograph taken after three months. The cystic formation in the foveal center enlarged.
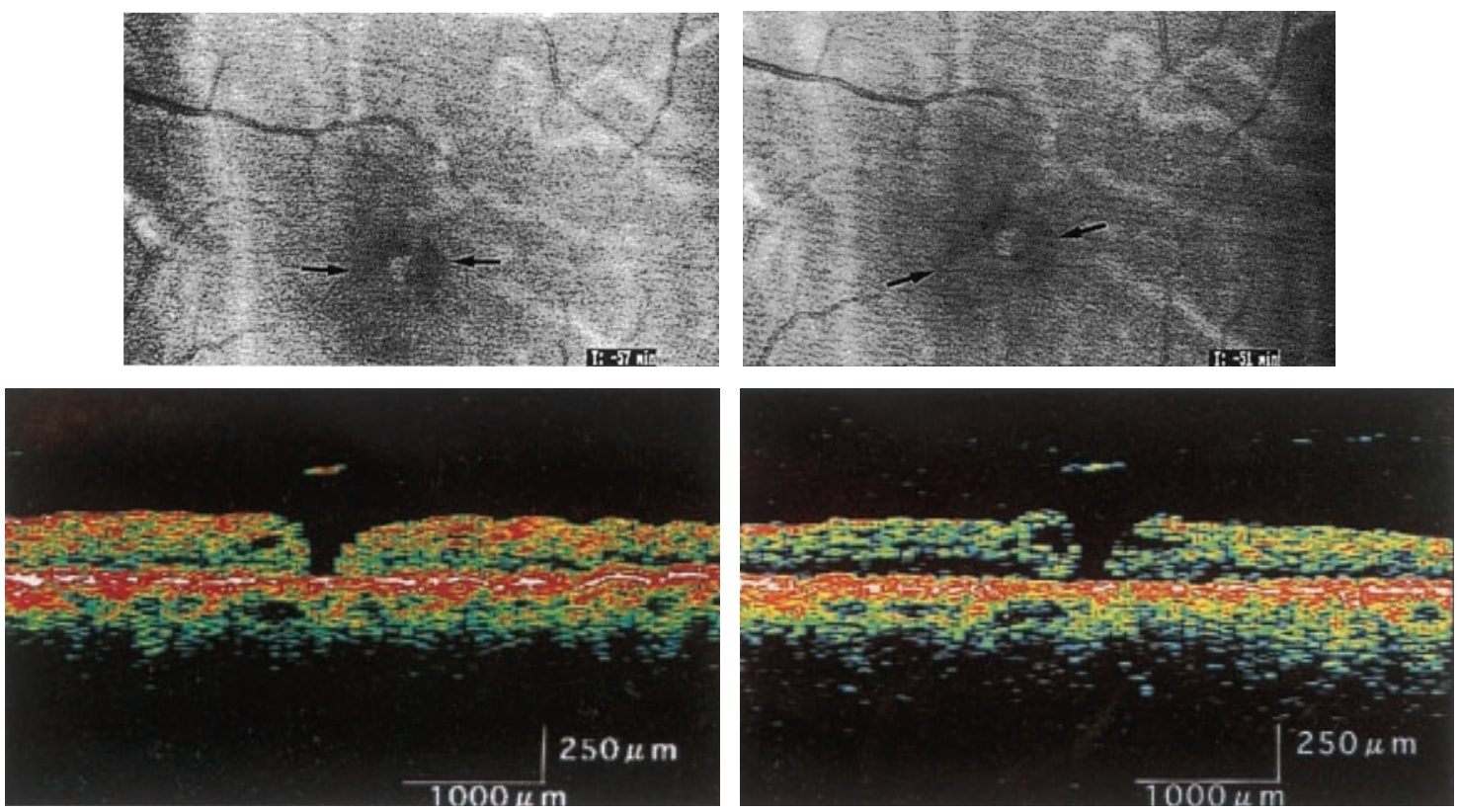

Fig. 2. Case 5. Stage 2 full-thickness macular hole. Top left, scanning laser ophthalmoscopy recorded at the initial visit. Helium-neon laser shows an elevated rim of foveal break. A dark area is seen (arrows). Bottom left, a horizontal optical coherence tomograph shows a full-thickness macular hole with attached operculum anterior to the hole and surrounding edema. Top right, scanning laser ophthalmoscopy performed after three months. The dark area enlarged (arrows). Bottom left, optical coherence tomograph taken after three months. Macular hole enlarged with detached operculum. 

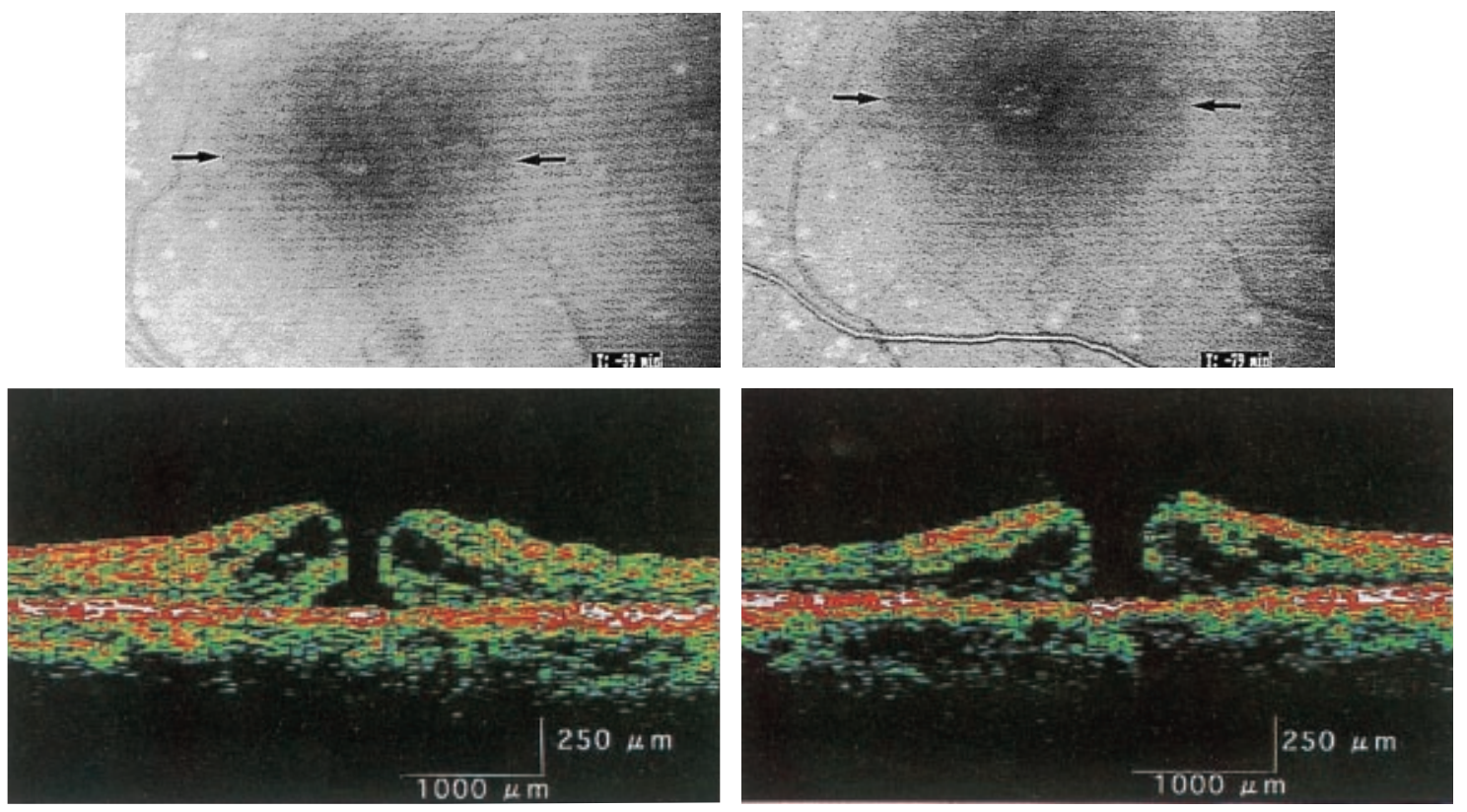

Fig. 3. Case 8. Stage 3 full-thickness macular hole. Top left, initial findings by scanning laser ophthalmoscopy. Helium-neon laser shows a macular hole with elevated rim. The dark area is seen around the hole (arrows). Bottom left, a horizontal optical coherence tomograph shows a full-thickness macular hole with cystic spaces in the surrounding neurosensory retina. Top right, scanning laser ophthalmoscopic image performed after three months. The dark area was enlarged (arrows). Bottom left, optical coherence tomograph taken after three months. Optical coherence tomograph shows sam finding as initial.
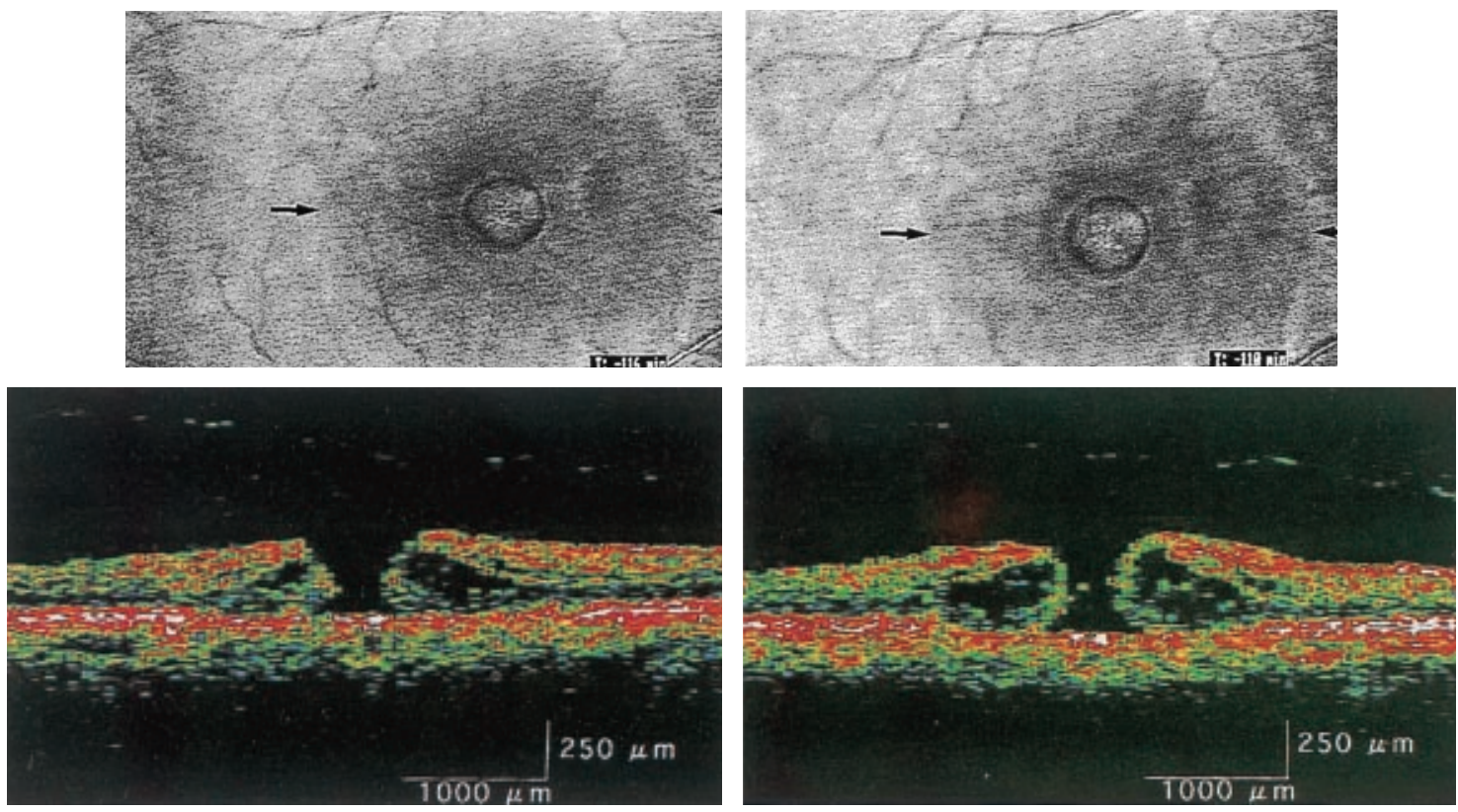

Fig. 4. Case 20. Stage 4 full-thickness macular hole. Top left, initial findings by scanning laser ophthalmoscopy. Helium-neon laser shows a macular hole with elevated rim. The dark area is seen around the hole (arrows). Bottom left, a horizontal optical coherence tomograph shows a full-thickness macular hole and a complete separation of the posterior hyaloid membrane from the retina. Top right, scanning laser ophthalmoscopy taken aftr three months. The dark area slightly decreased (arrows). Bottom left, optical coherence tomograph taken after three months. Optical coherence tomograph shows same finding as initial. 


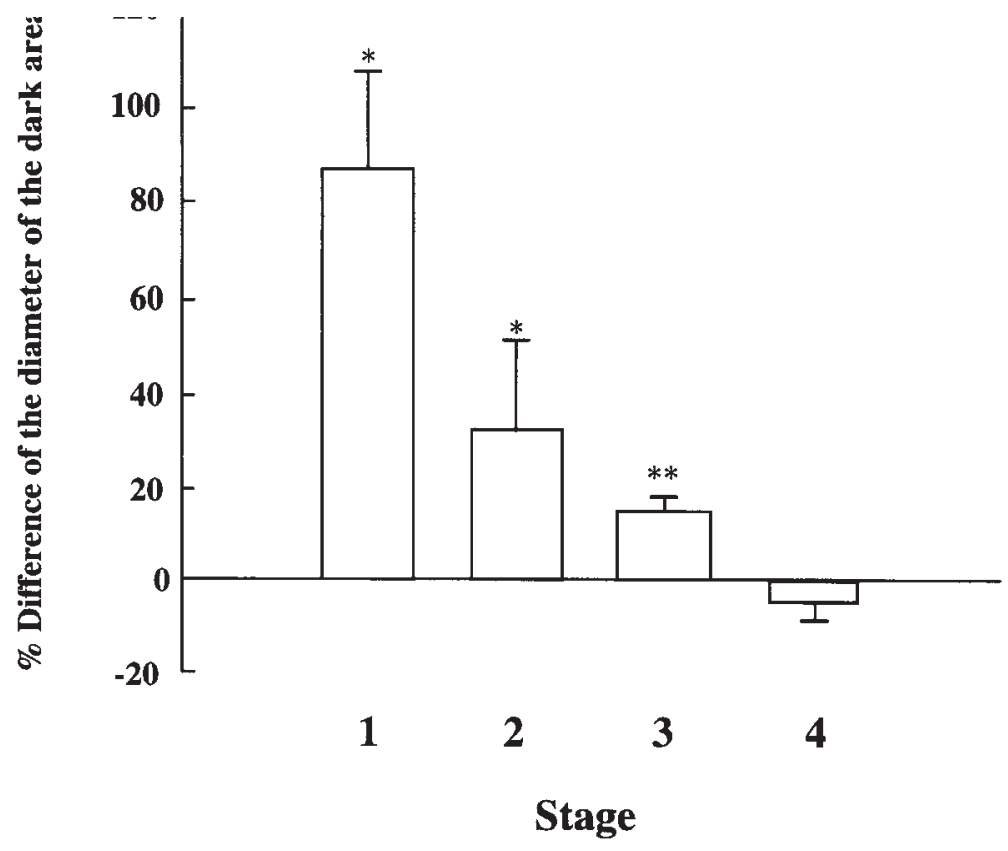

Fig. 5. Percent difference of the size of the dark area between initial findings and those taken after three months. Histograms show the comparison at each stage. ${ }^{*} p<0.05,{ }^{* *} p<0.01$, Student's $t$-test. Data are mean \pm s.E. Stage 1, $n=4$; Stage 2, $n=3$; Stage $3, n=13$; Stage $4, n=8$.

The size of dark area was significantly increased in eyes with stages $1,2(p<$ $0.05)$, and $3(p<0.01)$ disease using Student's $t$-test. The size of dark area was decreased in stage 4 . The percent difference of the dark area of stages $1,2,3$, and 4 between initial findings and recordings after three months was $87.5 \pm 40.14$, $31.93 \pm 19.35,15.00 \pm 2.86$, and $-4.37 \pm 3.12$, mean \pm s.E., respectively (Fig. 5 ).

\section{Discussion}

In the healthy eye, the central fovea comprises only the photoreceptor layer and the outer plexiform layer or Henle's fiber layer. It is surrounded by the bipolar cell layer, which is $350 \mu \mathrm{m}$ in diameter, and by the ganglion cell layer, which is $400 \mu \mathrm{m}$ in diameter. Macular holes are always round and from $350 \mu \mathrm{m}$ to $640 \mu \mathrm{m}$ in diameter (Chew and Sperduto 1999). It has been thought that macular holes were caused by tangential traction of the premacular vitreous cortex (Gass 1988; Guyer and Green 1993). Subsequently, many investigators have provided support for this theory.

The tractional elevation of Henle's fiber layer (OPL) with intraretinal foveolar cyst formation is the initial feature of the macular hole development in the SLO image (Kishi et al. 1995). We can observe a dark round area surrounding a macular hole with the SLO helium-neon laser, which has a long wavelength, and penetrates the deeper retinal layer to allow visualization of the intraretinal structures. We observed the dark area contained cystic spaces in Henle's fiber layer in cross-sectional image of OCT. Furthermore, We confirmed that cystic 
spaces were in proportion to dark areas with statistical significance as shown by correlation analysis $(p<0.05)$ (Akasaka et al. 1999). In addition to our results, postmortem examination of eyes with macular cyst showed the cystic cavity to be present between Henle's fiber layer and the photoreceptor layer at the foveola (Guyer et al. 1990). Therefore we speculated that the dark area corresponds to the cystic spaces in Henle's fiber layer morphologically.

Other hypotheses have been formulated regarding the mechanisms of macular hole formation. Intravitreous anteroposterior traction was been suspected to be the cause of macular holes (Avila et al. 1983). Gaudric et al. (1999) have been using OCT to detect the hyaloid remains adherent to the foveal center, indicating the action of anteroposterior force. Our findings showed that (1) in stages 1-B, 2, and 3 the diameter of the dark area increased over the time course, (2) the percent difference of the dark area between initial findings and after three months was larger in the early stage. These observations may suggest presence and disapperance of vitreoretinal traction around the fovea during macular hole development. We thought that the size of the dark area in stage 4 decreased because of the loosing of the anteroposterior forces.

The Gass classification (Gass 1995) for the stage of macular holes has been widely recommended. However, the development of the area surrounding macular holes was not so well investigated. This report describes a way to demonstrate developing macular holes by using SLO. The dark area using a helium-neon laser is thought to be a significant area for explaining the development of macular holes. In the stage before posterior vitreous detachment (PVD), the dark areas increased. Once PVD occurred, these areas decreased. These findings suggested that the time course of the dark area may be related to the development of PVD.

\section{References}

1) Akasaka, Y., Nishikawa, S. \& Tamai, M. (1999) Analysis of the retinal edema of full-thickness macular holes by scanning laser ophthalmoscopy and optical coherence tomography. Tohoku J. Exp. Med., 189, 233-238.

2) Avila, M.P., Jalkn, A.E., Murakami, K., Trempe, C.L. \& Schepens, C.L. (1983) Biomicroseopic study of the vitreous in macular breaks. Ophthalmology, 90, 12771283.

3) Chew, E.Y. \& Sperduto, R.D. (1999) Clinical course of macular holes. Arch. Ophthalmol., 117, 242-246.

4) Gass, J.D.M. (1988) Idiopathic senile macular hole: Its early stages and pathogenesis. Arch. Ophthalmol., 106, 629-639.

5) Gass, J.D.M. (1995) Reappraisal of biomicroscopic classification of stages of development of a macular hole. Am. J. Ophthalnol., 119, 752-759.

6) Gaudric, A., Haouchine, B., Massin, P., Paques, M., Blain, P. \& Erginary, A. (1999) Macular hole formation. New data provided by optical coherence tomography. Arch. Ophthalmol., 117, 744-751.

7) Guez, J.E., Le Gargasson, J.F., Massin, P., Rigaudiere, F., Grall, Y. \& Gaudric, A. (1998) Functional assessment of macular hole surgery by scanning laser ophthalmos- 
copy. Ophthalmology, 105, 694-699.

8) Guyer, D.R., Green, W.R., de Bustros, S. \& Fine, S.L. (1990) Histopathologic features of idiopathic macular holes and cysts. Ophthalmology, 97, 1045-1051.

9) Guyer, D.R. \& Green, W.R. (1993) Idiopathic macular holes and precursor lesions. In: Proceedings of the Symposium on Retina and Vitreous, New Orleans, Kugler Publications, LA, New York, 135-162.

10) Hee, M.R., Puliafito, C.A., Wong, C., Duker, J.S., Reichel, E., Schuman, J.S., Swanson, E.A. \& Fujimoto, J.G. (1993) Optical coherence tomography of macular holes. Ophthalmology, 102, 1748-1756.

11) Kishi, S., Kamei, Y. \& Shimizu, K. (1995) Tractional elevation of Henle's fiber layer in idiopathic macular holes. Am. J. Ophthalmol., 120, 486-496.

12) Mainster, M.A., Timberlake, G.T., Webb, R.H. \& Hughes, G.W. (1982) Scanning laser ophthalmoscopy. Clinical applications. Ophthalmology, 89, 852-857.

13) Swanson, E.A., Izatt, J.A., Hee, M.R., Huang, D., Lin, C.P., Schuman, J.S., Puliafito, C.A. \& Fujimoto, J.G. (1993) In vivo retinal imaging by optical coherence tomography. Opt. Lett., 18, 1864-1869. 